\title{
Counternarrative and antenarrative inquiry in two cross-cultural contexts
}

\author{
David M. Boje* \\ Management Department, \\ New Mexico State University, \\ Box 30001, MSC 3DJ, \\ Las Cruces, NM 88003-8003, USA \\ Email: dboje@nmsu.edu \\ *Corresponding author
}

\section{Marita Svane}

Department of Business and Management, Aalborg University,

Fibigerstraede 2, 9220 Aalborg Øst,

Aalborg, Denmark

Email: msvane@business.aau.dk

\section{Erika M. Gergerich}

School of Social Work,

New Mexico State University,

Box 30001, MSC 3SW,

Las Cruces, NM 88003, USA

Email: egerger@nmsu.edu

\begin{abstract}
We developed a theory of an antenarrative practices in relation to the interplay of dominant cultural narratives and counternarratives of resistance. Antenarrative is defined here as the field of forces Before, Between, Beneath, Bets and Becoming that occurs in the reduction of diverse living stories of Self to hegemonic narratives and counternarratives. We contribute two case studies of the ways antenarrative processes accomplish the hegemony, and the resistance occurring between dominant narrative and counternarrative. In the first case, dominant cultural narratives of homelessness are resisted by counternarrative theatrical performances by developing micropolitic antenarrative threads to bring what is Before, Beneath, Between, and Becoming to the fore, so that alternative Bets on the future become presented to audiences. We also offer an antenarrative inquiry into counternarrative and narrative cultural stereotypical representations of race, class and gender, and offer theory and methodology resources for a more meaningful understanding of homeless life and cultures. The second case explores narrative-counternarrative and antenarrative inquiry into a cross-cultural merger between two companies. Both cases contribute to how the storytelling world is an interplay of dominant narratives and their counternarratives, and the undercurrent of antenarrative processes.
\end{abstract}


Keywords: antenarrative; counternarrative; cross-cultural; culture; fractal change; hegemony; narrative.

Reference to this paper should be made as follows: Boje, D.M., Svane, M. and Gergerich, E.M. (2016) 'Counternarrative and antenarrative inquiry in two cross-cultural contexts', European J. of Cross-Cultural Competence and Management, Vol. 4, No. 1, pp.55-84.

Biographical notes: David M. Boje holds the Wells Fargo Professorship, Distinguished University Professor, and Bill Daniels Ethics Fellow in Management Department at New Mexico State University. He also has an Honorary Doctorate from Aalborg University, with a special affiliation to the Material Storytelling Lab. He is founder of Embodied Restorying Process. Vita at $h$ ttp://davidboje.com/vita

Marita Svane is an Associate Professor in Department of Business and Management at Aalborg University, Denmark.

Erika M. Gergerich is a College Professor, School of Social Work, College of Health and Social Services, New Mexico State University.

\section{Introduction}

Each organisation has a more or less branded narrative of the founding history and mission for being-in-the-world. Organisational narratives have been defined as retrospective (backward looking) with the plot coherence of beginning, middle, and end (i.e. BME narratives). Lyotard (1979/1984) describes grand bureaucratic narratives (or metanarratives) as being somewhat oppressive to people's lived stories. There is a web of living stories that do not make it into dominant organisational narratives, and do not have BME coherence. The organisation's cohered narratives and people's own living stories are not the totality of the storytelling going on in a community. There are also antenarrative threads that permeate each storytelling field, accomplishing transformations of grand narratives and living stories that are in the middle of being lived through. Boje (2001) worked out the first two aspects of antenarrative: ante defined as 'Before' narrative coherence, and ante as 'Bets' on the future potentialities.

In this article, we developed two case studies of the quantum storytelling field, focussing, in particular, on counternarratives. Counternarrative is commonly defined as a narrative that is in opposition or resistance to another narrative (Westley, 2009, p.vii; Webster, 2000, pp.384-385; Bovana, 2010, p.87; Nourse, 1997, pp.386-387; Shane, 2009; Leo, 2008). Lindemann-Nelson (1996, 1997, 2001) is said by Harter et al. (2006, p.6) to have coined the term 'counternarrative' to mean "'a cluster of histories, anecdotes, and other fragments woven together to disrupt stories of domination,'...'a story [or narrative] that resists an oppressive identity and attempts to replace it with one that commands respect'." (Lindemann-Nelson, 2001, p.6, bracketed additions ours). However, with a bit of research, one can come up with a long list of scholars who used the term counternarrative in ways relevant to this article prior to Lindemann-Nelson (Banning, 1980; Spivak, 1984; Lipsitz, 1988; Linton, 1989; Davis, 1991; Kubayanda and Kubayanda, 1989; Somers, 1991; Siddiq, 1992; Tyagi, 1995; Cruikshank, 1992; Dunleavy, 1993; Thomas, 1993; Mankekar, 1994; Ogundele, 1995). That said, 
counternarrative remains under theorised, and defining it as just a countermove to some other narrative does not, for us, result in understanding the dynamics of the quantum storytelling field.

A promising direction is how counternarrative, just as narrative, is used to show privilege to one race, gender, ethnicity, class or culture over another. Nourse (1997), for example, says Foucault's genealogy redeploys race as a counternarrative to pyramid structures of sovereign power. German (2009, p.ii) collects counternarratives to the dominant narrative claims about the 'academic frailty of first generation students and students of color.' When Golda Meir declared 'Palestinians do not exist,' (Alajaji, 2013, pp.98-99) that cultural narrative creates an erasure and an empty space for settlement. The narratives and discourse of the 1970s and 1980s placed Palestinian "cultural practices and realities of life in exile in different temporalities, countering the daily trials of the present in exile with cultural practices that were firmly anchored in the past. Indeed, cultural practices did not function as mere reflections of refugee life, but offered a counternarrative, or, rather, an antidote to it” (El-Ghadban and Strohm, 2013, p.183). Spivak (1984) is also using counternarrative to get at the alterity, the Beneath aspects of power and domination in intercultural settings.

The purpose of this article is to contribute an antenarrative theory and method that will unpack the subtle relationships between narrative and counternarrative in the practice of power and domination in everyday life (de Certeau, 1984). For us, the contribution is how the antenarrative communicative practices operate in what Anton (2001, p.77) calls the 'micropolitics' and 'microsocial' of lived-body world-experiences that are onceoccurrent, yet, for us, are the embodied fabric out of which lived story and grand narrative reductions get constructed, and changed in the dramaturgic events of spacetimemattering (STM). STM is the inseparability of spatialising, temporalising, and materialising of ongoing everyday lived-body interactions.

The structure of the article begins with an overview of antenarrative theory and methodology. This is followed by two case studies. We follow this with a discussion of the ways antenarrative contributes to narrative-counternarrative inquiry and practice.

\section{Antenarrative theory and methodology}

Boje (2014), Haley and Boje (2014), Boje, Haley and Saylors (2015), Svane and Boje (2015), Boje and Henderson (2014) and Henderson and Boje (2015) began working out three additional aspects of antenarrative: ante as 'Beneath' narrative and living story, 'Between' them, and 'Becoming' of care (and uncare) in the storytelling field itself. Each of the aspects is worked out in relation to Heideggerian ontology in his 'fore' notions, which are interrelated and entangled with one another:

- Antenarrative-Before narrative coherence (fore-having); “Any assertion requires a fore-having of whatever has been disclosed; and this is what it points out by way of giving something a definite character” (Heidegger, 1962, p.157).

- Antenarrative-Beneath narrative and living story web (fore-conception); “Anything understood which is held in our fore-having and towards which we set our sights 'foresightedly', becomes conceptualisable through the interpretation... it is grounded in something to grasp in advance-in a fore-conception” (Heidegger, 1962, p.150). 
- Antenarrative-Between narrative and living story (fore-structure); “All interpretation operates in the fore-structure, which we have already characterised” (Heidegger, 1962, p.152).

- Antenarrative-Bets on the future potentialities that are a multiplicity of paths to choose among (fore-telling); Fore-seeing can be short-sighted or far-sighted in 'the existential meaning of the hermeneutical/situation of a primordial analytic of Dasein' and once again 'the authenticity of potentiality-for-Being-one's-Self' and the 'meaning of the Being of care' Care and Selfhood ... (p.316).

- Antenarrative-Becoming of care (and uncare) in the storytelling field itself (forecare); the care-structure includes the phenomenon of Selfhood as 'the Ontological Meaning of Care' (p.323).

These antenarrative practices happen in the prereflexive fabric of communicative practices out of which lived story and the more generalising and universalising grander narratives are constructed. We call this 'quantum storytelling' (Boje and Henderson, 2014).

Figure 1 Quantum storytelling field. Designed by David Boje, drawn by Marita Svane (see online version for colours)

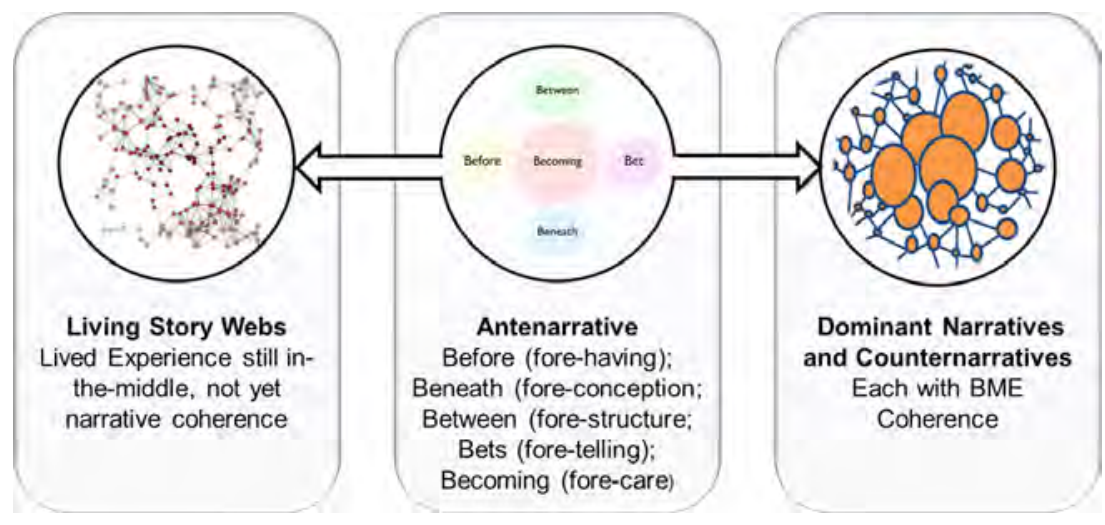

The 'quantum storytelling field' theory has been worked out in several books (Boje, 2014; Boje and Henderson, 2014; Henderson and Boje, 2015) and articles (Haley and Boje, 2014; Boje et al., 2015; Boje, Haley, and Saylors, 2015; Svane and Boje, 2015; Boje et al., in press), and is the topic of the annual Quantum Storytelling Conference (http://quantumstorytelling.org). The quantum storytelling field is defined here as relation of grand narratives and living story webs, with antenarrative threads playing important prereflexive transformative relationships in STM. STM is the inseparability of spatialising, temporalising, and mattering in the ontological situation. 
Figure 2 Five ontological aspects of antenarrative inquiry (see online version for colours)

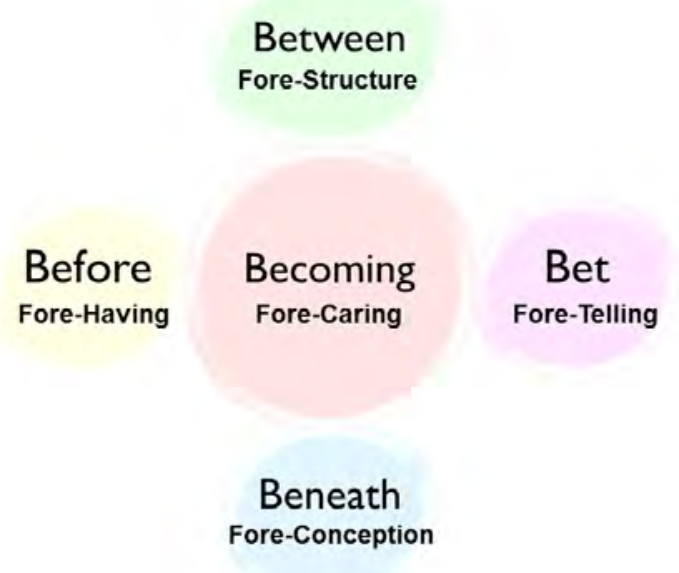

The above figure which theorises the relation of antenarrative to the fore-having, foretelling (aka fore-sight), fore-conception, fore-structure and fore-care is developed by Martin Heidegger (1962/1927) in Being and Time. Above we have linked the 'fore' notions to the antenarrative aspects of storytelling. Next, we developed the first case to work out the antenarrative inquiry into narrative-counternarrative.

\section{First case: homelessness and (un)care narratives and counternarratives}

We have been doing an extended ethnography of homelessness, including homeless veterans in New Mexico. We began by collecting field observations at a city's Housing Authority operation of a 30-unit apartment to house homeless veterans. This resulted in doing a study using sandtray work where veterans depicted their life story using action figures and other small objects in a sandtray (Boje and EnglandKennedy, 2013) and doing equine-assisted psychotherapy processes with student veterans and their families (Flora et al., in review; Rosile et al., 2015). Boje and Gergerich, then, continued work with the veterans of the HUD apartments and eight homeless veterans, as well as twentytwo other homeless individuals living in tents as a form of transitional housing at Mesilla valley community of hope (MVCH).

Mesilla valley community of hope manages the building and property at 999, West Amador Avenue, which is owned by the city of Las Cruces. MVCH is an alliance of several social service agencies working with the homeless: St. Luke's Health Care Clinic, El Caldito Soup Kitchen, Jardín de los Niños daycare center for homeless and nearhomeless children, Casa de Peregrinos Emergency Food Bank, the Closet de Mesilla Valley Clothes Bank, and Fairlight Community Gardens. MVCH is located on one side of Amador Avenue.

A second alliance of homeless serving organisations, located across the busy street, is known as Gospel Rescue Mission (GRM). GRM has separate dorms for homeless men and homeless women, serving a total of 110 people. They also operate a soup kitchen. 
GRM is an alliance of the Evangelical Council of Fiscal Accountability, the Combined Federal Campaign, the Association of Gospel Rescue Missions and the Community Foundation of Southern New Mexico. In the properties between and around MVCH and GRM, there are some 20 small and commercial businesses.

While other cities are passing ordinances making it illegal to feed the homeless and enforcing codes that prevent homeless from living in tents within the city limits, Las Cruces is among the few cities that have created a model program which planners from other cities are studying (Hosford, 2015).

\begin{abstract}
"Squatting was common on the city-owned campus of large, stucco buildings that MVCH shares with other social service providers. In 2011, after reports of drinking, graffiti, and other disturbances, the city ordered MVCH to clear the property. MVCH pushed back. Where would the homeless go? Existing housing programs were full, and shelters didn't offer accommodations for many homeless (those with dogs or partners, for instance) or long-term assistance" (Hosford, 2015, p.8)
\end{abstract}

In dominant cultural narratives, often the homeless families get stereotyped to be different from those with homes (Hunt, 2007). This leads to oppositional counternarratives to those narratives on the part of those feeling all lumped together by character stereotyping and experiencing the consequences of domination, rooted in myths (Table 1).

To counter these stereotypes constructed into narratives in our homeless community, we deploy amateur 'Veterans Theatre' that combines theatric sketches, singing and music inspired by homeless participants as a form of counternarrative, a resistance to homeless stereotypes in western dominant (grand) narratives. The Veterans Theatre counternarrative is theatrically an opposition, a resistance to stereotypes that homogenise homeless to be of one character in narratives. Counternarratives to the homeless stereotypes of the drug-using, panhandling vagabonds is the primary goal of the Veterans Theatre programs put on by the homeless from Camp Hope in Las Cruces, New Mexico. Ironically, counternarratives form their own stereotypes of the 3.5 million homeless in US.

Veterans are overrepresented in the homeless population (Perl, 2014). The National Coalition for Homeless Veterans (NCHV) reports that $12 \%$ of the adult homeless population and $20 \%$ of the male homeless population are veterans. Half of homeless veterans suffer from disabilities or mental illness (National Coalition for Homeless Veterans, n.d.). Returning veterans may not receive the services that they need which puts them at greater risk of homelessness.

The purpose of Veterans' Theatre is to bring the lost art of storytelling back to life. We practice increased communicability of veterans and the Veterans Administration (VA) social workers. We do our critical dramaturgy to restore to life storytelling practices that bring a new vigour to not only storytelling at the VA, but resuscitate storytelling in the USA. We are here to relaunch storytelling! Storytelling has collapsed and has yet to be resurrected. In this way, the dead art of storytelling is resurrected. In a land where veterans can no longer tell a tale of trauma properly, we are reclaiming lost storytelling competencies and putting them on the theatre stage. 
Table 1 Ten Homelessness myths (adapted from SuitcaseClinic.org) ${ }^{\mathbf{1}}$

1. Homeless people are lazy. In fact, over $45 \%$ of people who are homeless have jobs while they are homeless. Joblessness also exists as many times wages do not translate into liveable earnings

2. Homeless people are alcoholics/drug addicts. In fact, about $35-45 \%$ of people who are homeless do have a substance abuse problem; however, the relationship between homelessness and alcohol and drug addiction is quite controversial. While addiction and drug use is prevalent, many homeless individuals use substances in order to selfmedicate, exposing a fundamental problem in our nation's lack of healthcare provision for the poor and homeless

3. Homeless people are crazy. In fact, $20-25 \%$ of the single adult homeless population suffers from some form of severe and persistent mental illness, the most common of which is depression. Consequently, many people develop mental illnesses while on the street

4. Homeless people are uneducated. In fact, many people who are homeless have high school diplomas or their GED, college degrees and even Masters Degrees

5. Homeless people want to be homeless. In fact, nobody in their right mind wants to become homeless. There are some people who are 'chronically homeless' who have lost faith in society; they do not think that there is another way out because of society's treatment towards the homeless

6. Homeless people are dirty/smelly. In fact, you would be unable to tell that many homeless people are as such. Many people living in shelters you would never know were homeless because they have a place to shower

7. It is your fault if you become homeless. In fact, people become homeless for a wide variety of circumstances such as family problems, abuse, mental illness, lost job, inability to pay rent (lack of affordable housing and lack of a living wage), no health insurance, substance abuse (alcohol or drugs) or natural disaster (hurricane, earthquake, fire, etc.)

8. Homelessness cannot happen to you. In fact, it can happen to anybody at any time. One out of three people working today are one or two missed pay checks away from being homeless, especially the 37 million people currently living in poverty. Of these, 3.5 million are homeless at any time of the year

9. Homelessness will never end. In fact, homelessness can end and will end once it is no longer acceptable in our society for another human being to be sleeping outside, in their car, in an abandoned building, or in a shelter

10. Homelessness is easy to get out of. In fact, it is not. It takes a lot of work for a person to move from homelessness to homefullness and obtain access to gainful employment based on a living wage, housing and healthcare, and networks of support are imperative

Specifically, we use Augusto Boal's $(1979,1995)$ methodology of developing improvisational sketches with the oppressed, and presenting that theatre to those in power, even inviting them to cross over the Perineum Arch, and move from spectator to actor, integrating the roles into what Boal calls, 'spectactor.' In Forum Theatre, for example, the audience, after watching a play, is invited to suggest scene changes, and even come on stage, and play the role of protagonist or antagonist, in order to try out different resolutions to a conflict, resolve power imbalance, or counter an exploitation. In our case, we worked with the homeless veterans of the HUD apartments, and other homeless members of Camp Hope, to develop stories that would shatter deep-seated stereotypes common in our community. Each act deals with a particular stereotype. 
Figure 3 ACT 1 storyboard (by Boje, used by permission) (see online version for colours)
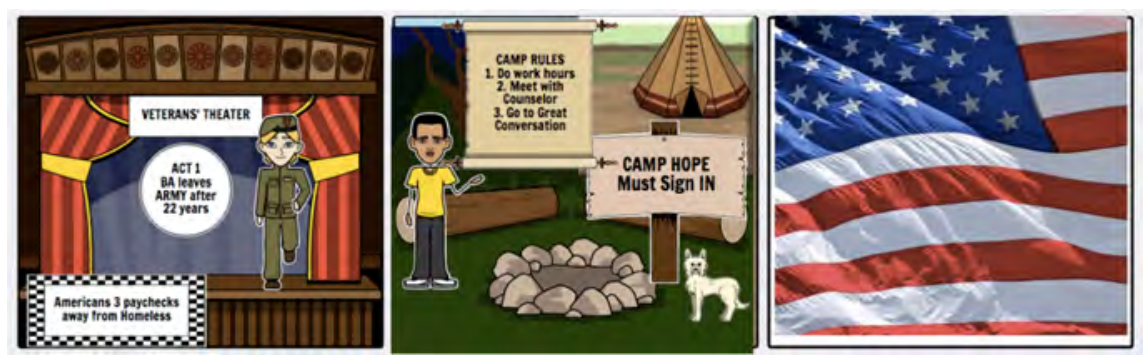

ACT 1: In the first Act, a female first Sgt. after 22 years in US Army retires after combat in the Iraq War. The Sgt. and her husband are hardworking, neither is involved with drugs, and they are working to get out of homelessness, which is not as easy as the dominant narratives suggest. The Sgt. tells her story of coming to Camp Hope, as Camp Hope veterans put up a tent for her to live in. She describes how she waited for her husband who was jailed on erroneous charges. The Sgt. and her husband stopped in Las Vegas (NV), and unbeknownst to them, a thief swapped out their license plates for stolen ones. At the New Mexico Border Patrol check point, the couple were pulled over for inspection. The plates were run, the husband arrested, the car and trailer impounded, and the Sgt. hitched a ride to Motel 6. She found a public defender, who was unsuccessful at convincing anyone that the couple had been a victim and not the perpetrators of a crime. Long after their money ran out, the American Civil Liberties Union (ACLU) interceded. Meanwhile the Sgt., money gone, went to Camp Hope, secured a donated tent, and moved in with her dog. Months went by, and the ACLU got her husband free, but the car and trailer, and all their worldly goods, had vanished. The Army Veteran, a former Military Policeman herself, and her husband have been living in Camp Hope for 8 months. At Camp Hope, the Sgt. is now head of the Security Team, keeping track of all 30 to 50 residents of the camp, noting their health conditions, so if something is wrong, she knows what to do, who to call, and so forth.

Figure 4 ACT 2 storyboard (by Boje, used by permission) (see online version for colours)

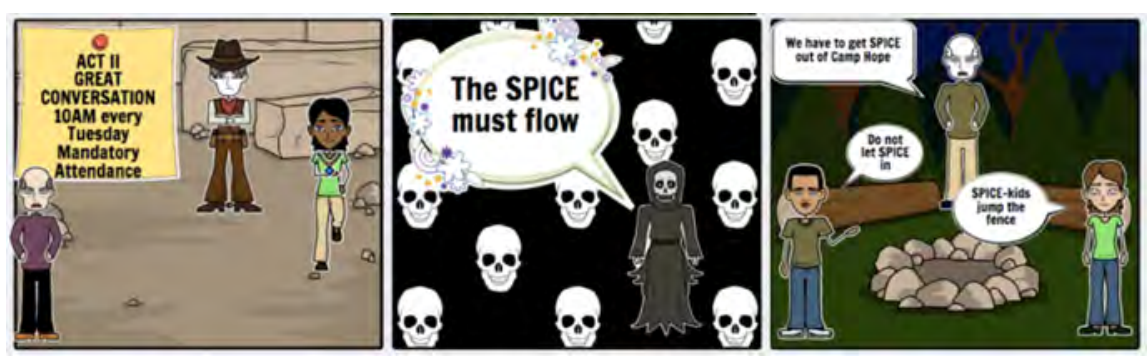

ACT 2: There is weekly roundtable discussion with the residents of CAMP HOPE to jointly decide their rules on how to deal with the 'spice heads' that encircle the camp. Great Conversations are weekly semi-formal discussions that take place among Camp Hope members, to discuss resident concerns. ACT 2 counters the dominant myth and stereotype that all homeless are on drugs. A frequent topic of concern among Camp Hope members, is the spice trade. The 'spice heads' jump the fence to steal items from Camp Hope residents. Homeless on homeless crime. Circling the camp are the spice pushers, 
each a small business owner, representing wholesalers, more small business owners. Spice is a \$121 billion business in North America. Keeping the spice flowing is the business of business. Spice is made in labs in China, Eastern Europe, and across the USA. 'In the last five years alone, more than 200 new synthetic drugs have been identified'-Washington Post 2014. One such manufacturer sells about 41,000 packets a month, delivered directly to 50 stores around the USA and shipping the rest to five other wholesalers, and earns $\$ 2.5$ million in revenue with $\$ 500,000$ in profits per year. Spice pushers surround homeless veteran camps and high schools across the USA. Our play is about how veterans are keeping spice heads out of their camp. It is the second most used illicit drug among high school seniors. Spice is a highly addictive designer drug, made with synthetic cannabinoids, also known as K2, Sexy Monkey, Black Mamba, Kush, Scooby snacks and Klimax. One inhalation can bring hallucinations or psychosis. Fatalities are reported mainly as suicides. The shiny packets all say, 'It's a potpourri' or 'incense', and 'not for human consumption!' Businesses that produce it are legal due to its mislabelling, and the fact when a given concoction of spice is declared illegal, the business owners just swap out a chemical or two, and once again distribute it.

Spice is a major topic at many of the weekly Great Conversations, since the two alliances of homeless services GRP and MVCH have different rules and policies concerning drug use. From a social work perspective, people facing addiction may experience relapse several times before successfully kicking the habit. The National Institute on Drug Abuse states that $40-60 \%$ of drug-addicted patients experience a relapse before successfully recovering. Before getting through a full year of abstinence, more than half of drug users will relapse (National Institutes of Health, 2008). Therefore, simply banning spice heads will keep them away from needed social services that might lead to a habit change. When spice heads act out, are confrontational and threatening, and get banned, it does not mean they are banned from every service and every provider. For example, a frequent discussion at Camp Hope is that banned people keep coming back for food. MVCH has a policy to reach out to spice users, as long as they are not violent. However, the rule of Camp Hope itself is to keep banned people out of the camp. This leads to tension when, for example, several church groups show up to work with the BBQ pit in our community garden they donated and helped install. Those church groups want to recruit lost souls to their congregation, to feed all the homeless, whatever their spice use may be or other situation. What is amazing is that the Camp Hope's weekly Great Conversation can negotiate the rules of the MVCH campus (the larger complex and alliance of service providers, each with their own rules) and the rules of the camp itself. In addition, across the street are 110 other homeless served by GRM's alliance of providers. The GRM residents cross Amador Avenue and seek clothing, food, healthcare and job referrals that are offered by MVCH.

Figure 5 ACT 3 storyboard (by Boje, used by permission) (see online version for colours)
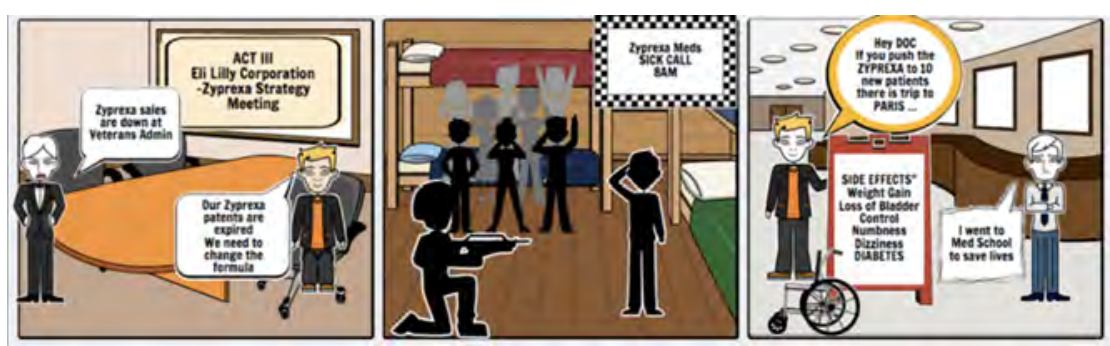
ACT 3: David Boje plays the CEO of Eli Lilly Corporation and fires a salesperson for a decline in the sales of Zyprexa (medication used for Schizophrenia); a second employee is promoted to sales representative to push the drug into VA use. Ernest Ramey plays the role of a VA doctor. In return for incentives, he agrees to prescribe the drug for more of his patients. The aim of this ACT is to speak back to the powerful pharmaceutical industry. There was much debate and deliberation at the rehearsals, as to whether to mention the name of the drug, Zyprexa, or a corporation as powerful as Eli Lilly. In the end, we decided that, since the company has been fined and convicted in a number of cases, we would go ahead and openly use the name Zyprexa in the play.

"Total revenue in the U.S. increased by $5 \%$ to $\$ 12.890$ billion due to higher prices, partially offset by volume declines for Cymbalta and Zyprexa ${ }^{\circledR}$ due to the loss of patent exclusivity." ... “Zyprexa sales outside the U.S. were $\$ 1.071$ billion, a $20 \%$ decrease driven by the unfavourable impact of foreign exchange rates, lower volume in markets outside of Japan, and lower prices.",2

However, there is another side to the Zyprexa story. It may not be safe: "Two patients have died unexpectedly after their Zyprexa Relprevv injections, and the FDA is now investigating. The agency says the patients died 3to 4 days after receiving 'an appropriate dose,' and both had 'very high' blood levels of olanzapine, the long-acting Zyprexa product's active ingredient."3

... Made by Eli Lilly (\$LLY), Zyprexa Relprevv is a follow-up to the company's blockbuster antipsychotic Zyprexa. The long-acting injectable version isn't a big seller for the company; Lilly doesn't even itemise its sales; it just reports the total Zyprexa franchise revenue, which amounted to $\$ 1.3$ billion last year. The Relprevv version is, however, still on patent, so it is selling at brand prices without generic competition. Its key patent expires in 2018.”....

"Zyprexa itself has come under plenty of FDA scrutiny. After years of reports of weight gain in Zyprexa patients, the FDA investigated, and the drug now carries a label warning of the risk of weight gain and metabolic problems. Lilly faced thousands of lawsuits from Zyprexa patients claiming the drug caused them to develop diabetes; the company wrapped up most of them in a $\$ 1.2$ billion settlement. The company also paid $\$ 1.42$ billion to resolve a Justice Department investigation into its Zyprexa marketing practices." ${ }^{4}$

“Among the allegations: That Lilly pushed Zyprexa for children and for elderly dementia patients, both off-label uses. That it made particular efforts to push Zyprexa in long-term care facilities and nursing homes. And that Lilly aimed to make Zyprexa a primary care drug, despite the fact that it was only approved to treat two disorders—schizophrenia and bipolar disorder-typically not handled by primary-care doctors. ${ }^{5}$

Figure 6 ACT 4 storyboard (by Boje, used by permission) (see online version for colours)
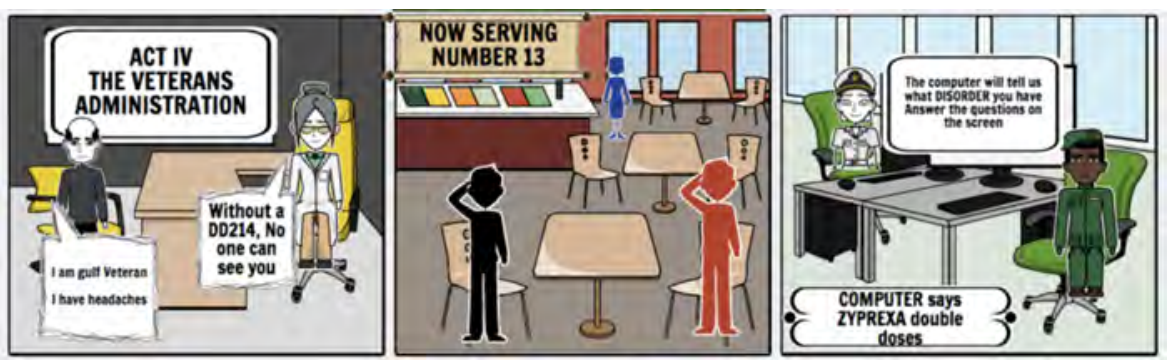
ACT 4: Three veterans go to the VA for care. They are first greeted at the front desk and hope to make their way through to see the team leader and nurse. Each veteran experiences various barriers while trying to receive services. One is unable to see the doctor due to not having the right paperwork. The second veteran, despite being gravely ill, is given an appointment date that is months away. The third veteran suffers a long wait for his appointment and then receives a speedy diagnosis and prescription. At six rehearsals, we practiced speaking out to power, in this instance, the Veterans Administration, and doing so with a sense of humour. Props such as a two-foot shot needle to administer Zyprexa were used. At the same time, there are significant issues to bring out, in ways that do not stereotype the Veterans Administration (VA), and leave space to invite them to problem solve, to enact some alternatives.

Here are some relevant facts. According to the VA, The care needed for 25.6 million living veterans is unsustainable given 'the federal budget climate. ${ }^{6}$ About 4 million of the 25.6 million total number of living veterans receive care in any given year. This means that VA does not have the budget for facilities, personnel, technology, meds and alternative therapies, to actually do the job. The VA strategy therefore has been to restrict and allocate care by giving priority access to veterans with service-connected disabilities. This means that most of the veterans committing suicide (22 per day) are not receiving any VA care. Of the 22 suicides a day, 21 do not receive any care at all. There are actually more deaths by suicide than by combat in the Iraq and Afghanistan wars, and that has never happen in the history of USA wars. With the lack of service options, and obstacles that make for long wait times, few of our local veterans go for services at the VA. In Las Cruces, New Mexico, e.g., 80\% of the veterans at Community of Hope do not seek or receive VA benefits. Rather, they exist on Medicaid, Medicare, or private care. The VA operates 162 VA hospitals nationwide. Totally 57 VA regional offices provide benefits to veterans. VA has medical care budget of more than $\$ 28$ billion, and employs more than 180,000 healthcare professionals in 162 hospitals, more than 850 community and facility-based clinics, 137 nursing homes, 43 domiciliaries, 206 readjustment counselling centres and various other facilities throughout the country. Of the 25.6 million living veterans, most (75\%) served during a war or an official period of hostility. Of these, over 6.2 million enrolled veterans look to VHA for healthcare services and more than 4.3 million veterans received care in FY 2002. "VA has been unable to provide all enrolled veterans with timely access to health care services because of the tremendous growth in the number of veterans seeking VA health care."7 One in four homeless are veterans, and half of these are from the Vietnam era.

Figure 7 ACT 4storyboard (by Boje, used by permission) (see online version for colours)
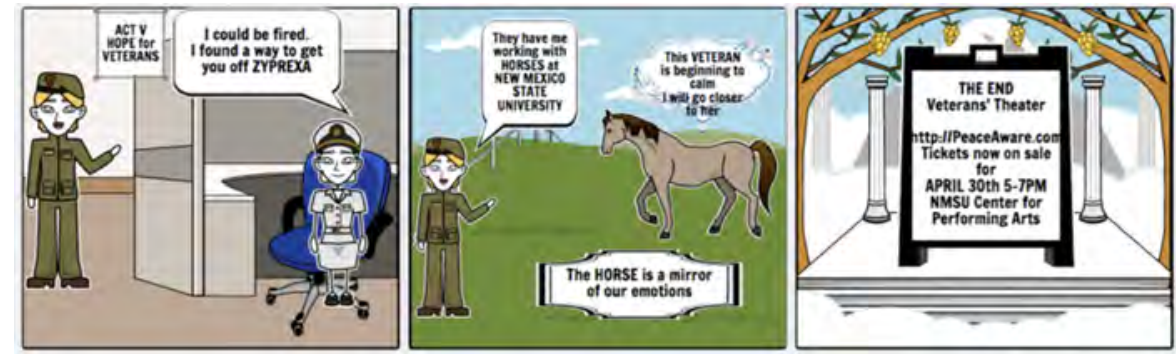
ACT 5: In Act 5, a US Marine, now homeless, has had his medications stolen and goes to see a VA social worker. The social worker finds a way around the bureaucratic system, so that Michael is able to have his medications replaced. We wanted to point out that it is possible to work with the social workers, nurses, doctors and team leaders at the VA to make things better, despite the limited budget. The veteran tells a story of how the local VA social worker has a 'Heart of Care' and does what it takes to convince the doctor to forget Eli Lilly incentives and simply get him the help that he needs. The play ends with the social worker asking the veteran if he wants to try alternative therapies, and suggests Legacy Ranch, a potential partnering of NMSU with the Veterans Administration (VA) and other military-serving organisations to be a healing place for military and their families. There are several places in the US where VA counsellors are working with equine-assisted and other alternative therapies.

\section{Resisting stereotypes of the homeless}

Resistance to the stereotype homeless-narrative, a counternarrative in which people are able to take pride and perform into 'Being' something not inscribed by dominant cultural characterisations, rather choreographing counternarrative of the Self, of many different kinds of homeless is neither romantic nor terminal. In the 1920s, the homeless were known as 'hobos' (Pittma, 1964). One of the stereotypes that homeless often encounter is that every homeless person is a spice head (defined as some who smokes spice, thinking that it is grass) ${ }^{8}$ Spice has numerous side effects: psychotic episodes, paranoia, increased anxiety, hallucinations, seizures, increased heart rate, uncontrollable body movements and lack of emotional attachment, and sometimes it is fatal. ${ }^{9}$ Spice is extremely addictive and relapse is common. The spatialising of homeless spaces, the temporising of time anchored in the past to misrepresent homeless life in the present, the materialising of every homeless person as spice head, the counternarrative to such narrative hegemony opposes the homogenising force and the manipulations of STM.

Dominant narratives re-historicise the homeless, and their history gets re-territorialised into different spatialities, temporalities, and materialities. What Gayatri Spivak terms 'strategic essentialism' in each 'hegemonic narrative' (p.102), makes the role of counternarrative performances a critical one, to put into play many homeless counter Selves, resisting the way the hegemonic narrative essentialness invalidates, erases, and reduces the particularised living stories. The courage it takes to enact counternarrative theatric performance in resistance to hegemonic cultural narrative, to open a multi-layered counternarrative of the homeless commit, that shows the entanglement with the hegemonic narrative against which Camp Hope exists, must also open up the antenarrative factor, how the transformation occurs, how the grand narrative soft homeless Self are kept alive, how the erasure of Other Selves takes place, and how to find life of the Self in everyday camp life.

Homelessness heritage has been commercialised and cheapened through narrative misrepresentation. There are consequences to performing homelessness stereotypes in cultural narratives. As much as dominant narratives rely upon traditional folkloric forms to counter dominant narratives, those folkloric forms become appropriated and adapted in ways that best fits the pragmatic needs of organisations. Therefore performing Veterans' Theatre on the NMSU Center for the Performing Arts, new stage, speaks to the paradox of counternarrative relying on folkloric expressive forms to counter dominant narrative 
homeless stereotypes, which are already appropriated to fit dominant cultural narrative needs. This is what Bakhtin identifies as double narrative: a dominant narrative using cultural material of the Other, for its own primary uses. The suppressed groups (homeless veterans) are treated as cultural material by the agencies, necessary to fund raising legitimacy (Fink, Holden and Lehmann, 2007).

The fractal patterns of homelessness are embedded in an inter-organisational field of non-profit service providers, businesses, university and government agencies. We can analyse the fractal patterns of the homeless inter-organisational field. In Las Cruces, there are two alliances of a network of non-profit service providers: Mesilla Valley Community of Hope (MVCH) and Gospel Rescue Mission (GRM). They occupy opposite sides of Amador Avenue just west of the railroad tracks. MVCH and GRM alliances are situated among some 20 businesses within a square mile area of the City of Las Cruces. One of the greatest myths of those who have never been homeless or worked with them is that homeless people are all the same. A variety of different kinds of homeless characters exist: the 50 or so who live in some 35 tents at Camp Hope in MVCH and the 110 or less homeless at either the men's, women's or volunteer's dorms of GRM, and the scores of other homeless that come there for services or to hang out, who are rough sleeping on the streets, or in cars, and in some cases homeless students sleeping in the libraries at NMSU and UTEP until they close for the night. All these organisations (non-profit, profit, government, education) have their own particular attunements to the world of the homeless. An attunement is defined as a 'mood' not a psychological state, rather an embodied tuned to and being tuned by Being-in-the-world (Heidegger, 1962).

There are many different kinds of homeless individuals. These various homeless characters interact with one another and with and/or against the various non-profit alliances, business, government agencies, and educational institutions. Therefore sociality is already always a given of the human condition of homelessness. Next we will explore the antenarrative vectors: Before, Beneath, Between, Bets, and Becoming.

\subsection{Before-antenarrative vectors}

The homeless world in all its variety is already socialised antenarratively before narrative coherence gets constructed. Antenarrative prereflective processes that are intentional always already socialise the homelessness world. Anonymous and upfront 'Others' are always already othering the homeless implicitly, prereflexively, tacitly by Beforeantenarrative vectors of intentionality. Antenarratives are always already orchestrating and regulating the sociality of homeless communities.

\subsection{Beneath-antenarrative vectors}

Beneath are the antenarrative fore-conceptions already sedimented out of which narratives and living stories are possible to fashion. The Beneath-antenarratives are sometimes in fractal patterns, iterating self-sameness at various magnifications of scalability (Henderson and Boje, 2015; Boje, 2015, in press). It is through the sociality of othering, in fore-conception, that the homelessness world repeats and changes fractal patterns. For example, homelessness and homefullness are constituted by duality, in which stereotypes make the agential cut, the divide between one and the other (Barad, 2007). Deconstructing narrative identity requires an antenarrative inquiry into the foreconceptions of the antenarrative vectors themselves that fashion existential correlates of 
the Self and the 'Other.' It is through antenarratives of Othering that the home-less/ home-full is what it is. 'Being-with-others' (Anton, 2001, p.55) is already antenarrative spatialising, temporalising, and materialising, what (2012), Hockenberry (2012), Boje and Saylors (2013), Jorgensen, Strand, and Boje (2013), Henderson and Boje (2015), Boje and Henderson (2014), and Bonifer (2014) call STM. STM is defined as the inseparability of space-time-mattering, how even dashes do not get at the complex dynamics of sociomateriality. Much of the STM happens through handiwork, both in terms of providing services to the homeless, such as clothing, blankets, tents, food, and in the illicit spice trade, where spice pushers prey on the poor. Handling things like donated goods and spice goods is the invisible supply chain that is daily tending to donations, the hand-off of things.

One Saturday, four churches came to Camp Hope to feed the homeless, to use the donated BBQ devices and congregate with the homeless in the part of camp that they had set up for joint church-camp activity. The camp is laden with material artefacts that are inseparable from spatialising and temporalising-STM: a long storage unit for donated clothes, a community garden, the photovoltaic (PV) units that Positive Solar Company of Las Cruces donated, several Eagle Scout projects earning them merit badges (a batter box for the PV unit, a shade structure for the community gardens), the tent pads framed in two by eights and filled with sand handiwork of several construction companies according to designs by Engineers without Borders, a faculty and student club at NMSU, the buried water tank placed by the Lion's Club beneath the BBQ area, etc.

\subsection{Between-antenarrative vectors}

It takes infrastructure to sustain the MVCH and GRM, and to sustain the spice trade, or to counteract it. The spice trade is big business. Spice products are advertised and labelled: 'Not for Human Consumption.' When a combination of spice chemicals is declared illegal, the hundreds of spice producers throughout the world change a chemical and it is once again legal. The lived-through world-experience of spice is something that all the homeless characters, be they volunteers at GRM, or doing guard duty or a member of the Safety Team at Camp Hope experience. In addition, in the day-to-day living-with spice pushers, spice heads, and casual spice users, the non-spice using homeless have to eat with, walk among and sleep among the lived-bodies of spice world. That spice world is supplied by products, tools and machines by many supporting industries to make spice, to distribute spice and to use spice. The Codes Enforcement Officers and city workers cut down a tree and removed clumps of Elephant Grass in the lot next to Camp Hope because spice heads were congregating behind it. Codes (as they are called in the Camp) also are dealing with the growing population of squirrels, burrowing everywhere, even up into tent sites. The owls that kept the squirrels in check have gone. Codes also deals with squatters-unauthorised homeless putting up a tent in the ditch just behind MVCH, or in the vacant lots.

\subsection{Bets-antenarrative vectors}

Since the homeless world is always already socialised in 'Others' othering, this 'enables a real-ising of otherwise undreamt potentialities' and 'capacities to dream otherwise' (Anton, 2001, p.54). In the antenarrative-bets communicative praxis, the future is choreographed and orchestrated already in the microstructure of othering homeless into 
characters. The diverse homeless groups (families, veterans, elderly, etc.) along with the non-profit alliances (MVCH, GRM) are making bets on the future.

\subsection{Becoming-care antenarrative vectors}

Becoming-antenarrative vectors are how MVCH and GRM attempt care for the homeless, and invite churches, universities, schools, civic groups, etc. to join in, to donate money or artefacts, time and energy to the cause. MVCH and GRM orchestrate the care-giving, providing a place for care to happen, organising the homeless themselves as volunteers to manage the artefacts (clothing, food, etc.).

Each of the antenarrative vectors existentially decompresses, being already a sociality of intentional power of othering. For example, the spice head and spice pusher have each gained a Self and lost his or her Self, and haunts MVCH and GRM as an 'Other.' The spice pusher and spice head choreographs and articulates antenarrative threads along with MVCH and GRM. The two alliances (MVCH and GRM) create inertias and obstacles for the spice pushers and spice heads. The spice world characters often are taking meals, clothing, showers, haircuts and other services from MVCH and GRM, unless they get banned. Being banned is rarely permanent. The user, for example, may attempt to kick spice five to a dozen times before long term change sustains.

\section{Second case: cross-cultural counternarratives between merging companies}

The second case we present, concerns the struggle between cross-cultural counternarratives and the antenarrative process towards the formation of a new fragmented yet dominating cultural narrative. The case is adopted from Svane (in press-a) and Svane and Boje (2014) and is further elaborated on in this chapter.

\subsection{Clusters of fragmented cross-cultural counternarratives}

The case is about a cross-cultural merger between two competing companies. Because of their long competitive history and inherited hatred, the merger was strongly opposed by a large group of stakeholders from especially one of the companies (Alpha House), including managers, employees, customers, and even—at least for a temporary time- the board of directors.

The merged company is a small and medium sized, agricultural, consultancy association with about 200 employees. Being a non-profit organisation, the company is owned by its customers. Due to profound structural changes of the agricultural sector since the middle of the last century and the impact of several economic and financial crises, the agricultural market is a challenging market to create, operate and service as the number of customers continuously decreases and the competition is severely intensified. As a reaction to this development, the industry shows a long history of mergers between various agricultural companies.

In line with this tendency, the company was established in 2008 as a result of a merger between two fiercely competing consulting organisations. In their turn, these two organisations also originated from previous mergers. Today, the merged company is composed of three consultancy 'houses' located in three different cities within the same 
main geographical market area: Beta House, Delta House and Alpha House. Beta and Delta House belong to the one of the two merging companies whereas Alpha House constitutes the other company. Headquarters are located in the Beta House. All three houses have developed their own cultures. As a consequence, the company is composed of an organisational mosaic of different countercultures related to the many mergers in the past. Both employees and managers address cultural differences between the three houses and the CEO, Steven, even refers to their internal conflicts as fights.

The strategic and economic advantages of the merger were clear enough. Due to the merger, the company became the largest consultancy company in its main market area and the fifth largest agricultural association in Denmark. With a presence in the three main cities, the company remains close to the local customers. Despite the obvious strategic and economic advantages, the merger did not make sense to all members of the new organisation. At the time of the merger decision, Alpha House had to choose between two competitors. Originally, they tried to merge with another competitor but when that failed, they ended up with Beta/Delta, thereby eliminating one of their biggest competitors. Not all organisational members, customers and owners agreed upon this decision, and it was only voted for by a marginal number of voices at the general meeting. The elimination of the competition between the two companies was considered to be a huge advantage, but due to severe conflicts in the history of the two companies, their relationship was rooted in mutual hatred and hostility, overshadowing the merger advantages. In Alpha House, they referred to the merger as 'marrying their worst enemy'.

The years following the merger were very challenging due to ongoing disagreements, conflicts and disputes. In two and a half years, the organisation thus experienced four different CEOs and a board of directors who discussed their disagreements in the public media. A drop in customer and employee satisfaction reflected the lack of trust in the company and the management. The conflicting, critical voices were raised openly as many employees and customers left the company to join the competitors. Hence, the 'usthem' counternarratives were reinforced during these years. The tendency continued for some years in the aftermath of the merger and significantly weakened the economic performance of the company. Not surprisingly, this development resulted in a growing deficit from 2008 to 2009, which seriously endangered the continued existence of the company.

This was the situation when Steven, the fourth CEO, was hired in 2010 to turn the company around. According to his storytelling, the previous management was not prepared for the challenges related to the integration phase of the merger, meaning that little or no efforts were made to bridge the counternarratives or to work with the negative construction of the other in the process of identity and culture formation. Also, they did not initiate discussions on the future organisation and strategic development of the company. In fact, they ceased to act, hoping that time would help the process of integration.

Consequently, the storytelling of the merged company included fragmented stereotyping cross-cultural 'us-them' counternarratives. When addressing the merged company, the organisational members and customers did not refer to a shared company identity but refer to 'us-them' narratives. Even two years after the merger, some employees from Alpha House kept on telling stories of their own company, pretending that the merger had not taken place. The counternarratives are, however, fragmented stories, as many cultures have been imported into each of the two organisations through their previous history of mergers. These fragments shine through in glimpse in their 
storytelling. However, the 'us-them' cultural counternarratives tend to prevail and dominate the storytelling whenever the conversations address the present state and future of the merged company.

Figure 8 Clusters of fragmented counternarratives (see online version for colours)
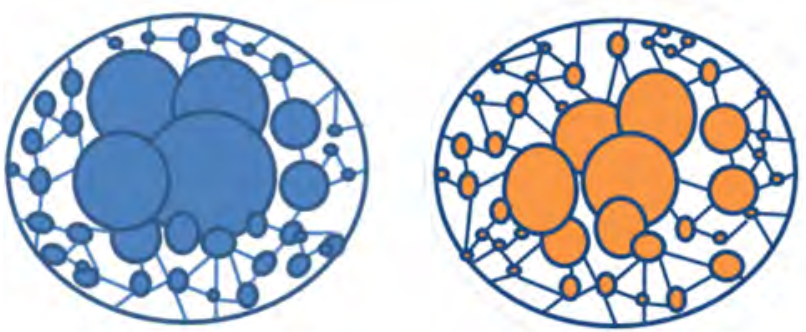

Hence, the 'us-them' cultural counternarratives can be understood as aggregated, stereotypical 'us-them' formations of culture and identity, each being a cluster of past stories and cultural fragments that are woven together and materialised in two opposing cross-cultural counternarratives.

\section{Antenarrative five B's process of cross-cultural organising and strategising}

Steven was hired in 2010 and stayed with the company until 2014, when he decided to withdraw from the company. During the 4 years, he initiated a merger integration process as well as a business and strategy development process. Involving all employees and managers in the merged organisation, as well as many customers, owners and the whole board of directors, he carried through a comprehensive strategy change process. Besides that, he also reduced costs by closing down a fourth house belonging to the Beta-Delta organisation in 2010, dramatically reducing the number of employees and managers, implementing changes to the performance management system and introducing lean in the organisation.

Considering the different cultures in the organisation and the hostile 'us-them' counternarratives, the CEO decided to facilitate a multi-participatory, bottom-up strategy process, divided into two steps. In the first step, all managers and employees, many customers and owners and the whole board of directors were asked to participate in the strategy formulation in a bottom-up process. For the second step, the employees were invited to participate in the work of implementing the strategy. If they joined the strategic project groups, they would be working partly with the strategic development of the company and partly with the operative tasks. Hence, strategy project groups were formed in relation to the strategic themes identified in the strategy formulation process. As part of the work in the strategic groups, the employees made sense of the strategic themes by relating them to their everyday life experiences and local knowledge. The managers participated in steering groups in order to coordinate resources, ensure sufficient organisational capacity for both development and operations and to assess new proposals forwarded from the strategic groups. During 3 days each year, all employees and managers were asked to participate in the evaluation of the strategy process. During these 
days, they made sense retrospectively of the past stream of actions and decisions, and prospectively towards the future: "We work with it all the time. Every year, we evaluate it; what we are doing, where we are heading, what we need to focus on..."-Team leader, Alpha House.

Consequently, the strategy continues to be enacted and further developed throughout the ongoing strategic work that is carried out by the strategic group members in their daily actions at the operative level and in the group work, where real life experiences are shared and new ideas for business development are brought up. "The strategic groups run their own life right now, more or less. Steven is actually not part of our strategy group. Once in a while, he is informed about the things that we work on. And only if he thinks that something is way out, then he interferes.”-Jill, Delta City, employee. The quotation indicates the practice level of the strategy process that is coped with by the employees without interference of Steven. The performative consequences of this microprocess are the ongoing strategic and business development as well as the ongoing organising processes of everyday practices.

Turning to the microlevel of new emerging situations, where concrete actions and decision making occur, relates this strategy process to the strategy practice approaches (Chia and Holt, 2006, 2009, Whittington, 2006), focussing on the process of strategising as part of the ongoing Becoming of the organisation. The practice-oriented approach to strategising links strategising and organising closely to each other by conceiving organisations to be 'a pattern that is constituted, shaped and emerging from change'(Tsoukas and Chia, 2002, p.567) in an ongoing process of becoming. In fact, strategising and organising tend to become inseparable processes in practice: '[T] he two run together as simultaneous activity', '[O]rganising part-shapes strategising', “[T]he skills and practices of strategising and organising are so similar and intermingled in action that it is hardly worth trying to tell them apart.” (Whittington et al., 2006, p.618).

The merger integration process is integrated into the strategising and organising process, as Steven made sure that all group work activities were composed by actors from the two merged companies and across the three Houses. As part of the cultural integration, Steven was not only considering how to bridge the two cultural counternarratives but also the multi-cultural narratives of the three Houses.

The microlevel strategising, organising, and cultural dynamics seem to be rooted in the antenarrative Beneath, rooted in the living story web and a fore-conception. Distributed through the living story web and shared in the strategy groups, living stories of real life experiences are centrifugally exchanged and ideally merged through the heteroglossic great dialogue, meaning that all voices participate in the dialogue with equal rights (Bakhtin, 1984, p.71). The view of merging lifeworlds through exchanges is shared by Bakhtin: 'Every thought and every life merges in the open-ended dialogue' (1984, p.293).

Sharing language is a heteroglossic process of culture and identity transformation. Heteroglossic means 'another's language in another's speech' (Bakhtin 1981, p.324). Utterances are heteroglossic because they are uttered in a language used in different social, cultural and historical context (Bakhtin 1986, p.428). Thus Bakhtin states: 'I live in a world of others' words' (1984, p.143). Others and words are embedded in lived cultural worlds and communities in time and place, but nevertheless part of the ongoing chain of heteroglossic communication. Not only may cultural lifeworlds merge through living story exchanges, but also identity may transgress. According to Bakhtin, identity is a dialogical transformation of 'how an individual becomes other than what he was' 
(1981, p.115). Clark and Holquist (1984, p.206), on Bakhtin, state that "An utterance is always between a self and an 'other' and constitutes the primal workings of selfidentification”. The following quotations indicate that the antenarrative Beneath process of merging living stories have changed the cross-cultural counternarrative between the merged companies, and between the three houses.
"It is properly the greatest success of interconnectedness; that we all take responsibility. We know what is in the strategy. We know what to do to make it work”.-Philip, Alpha City, employee.
"At that time [before the new CEO], we did not feel that we were one big family. But his way of approaching this made us feel more like being employed in ONE organisation. It was a long journey because we had to get used to it but both the social and professional cooperation is much different today."-John, Delta City, employee.
"It has become much better, but to begin with, I think we all were frustrated, because we were used to manage our own little house. And there was a feeling of... did we dare share with the others? Or would they play games with us? That has disappeared today.”-_Jill, Delta City, employee.

The cross-cultural organising of the strategising process as presented above indicates that "polyphonic, heteroglossic dialogues allow [...] living stories of life-worlds to merge culturally, socially and historically and produce new multi-voiced, merged living stories as well as language development and new materialised relationship practices. Consequently, the merging process between living stories is changing the foreconception, and hence the configuring of STM of the cross-cultural organisation. By nature, this process is a co-creative, relational, and materialising entangled process of coming-into-being of person and lifeworld." (Svane, in press-b, p.17). Strategy, organisation, culture and history are entangled processes of becoming: “...strategymaking must be construed as a collective, culturally shaped accomplishment attained through historically and culturally transmitted social practices and involving dispositions, propensities and tendencies” (Chia and MacKay, 2007, p.236)

The merging of different cultural and organisational lifeworlds relates not only to the antenarrative Beneath process but at the same time also to the Between process of antenarrative fore-structuring and re-configuring STM. The change of the cross-cultural counternarratives thus seems to be accompanied by emerging and materialising relational re-constructions of cultural identities, interaction patterns, and organisational, cultural interconnectedness.

Following Heidegger, interpretation operates in the fore-structure, in a disclosing circle of openness based upon involvement (Svane, in press-b, p.27): "In interpreting, we do not, so to speak, throw a 'signification' over some naked thing which is presentat-hand, we do not stick a value on it; but when something within-the-world is encountered as such, the thing in question already has an involvement which is disclosed in our understanding of the world, and this involvement is one which gets laid out by the interpretation” (Heidegger, 2008, pp.190-191). Being involved means Being-open in Being-within a practical, embodied and emotional engagement with the world. The forestructuring process implies that all past oriented interpretations can be modified; that is, all predefined/preinterpreted meaning structures only work as a fore-structuring of the world in its process of becoming. Interpretations contribute to make the world familiar and intelligible, a place where we are at home; it allows us to dwell and enables us to 
involve and engage (Svane, in press-b), and yet it can be modified into new ways of interpreting and understanding.

Interpretations operating in the fore-structure relates to the antenarrative process of operating Between narrative and living stories. Perceived as a fore-structure, the narrative may be open for changes, when storytellers involve and participate in relational living stories that challenge the narrative constructions based upon dissensus, ambiguity, paradoxes and contradictions. Hence, the past narrative configuration of STM, and thus of identity and culture, may change in a re-storying or retelling process as part of the antenarrative Between.

As simultaneously intertwined parts of the interplay between Beneath and Between processes of organisational becoming, the organisational members are at the same time fore-having its future in the antenarrative Before, and antenarratively Betting on the future to become.

Different strategic bets were foretold based upon the warning signals of the market and environmental development and the economic performance of the company. The fore-telling of one bet concerns the continuing decrease of the agricultural market resulting in the closing down of the company. This fore-telling collapses into a narrative of the burning platform of the company which becomes widely accepted by the organisational members, taking seriously the warning signals. Another bet anticipates a new merger within a relatively short-term time horizon with, eventually, the most important and most hostile competitor in the geographic area. Future merger activities may pave the way for the increase of market shares, the elimination of competition, the reinforcement of a market position and improved economic performance. A third bet concerns the survival of the company on its own through business development as a way to proactively create new business opportunities in order to compensate for the loss of customers and profit. Hence, business development emerges as a strategic theme to be elaborated and worked upon in the strategic groups.

To pave the way for this third attractive future to arrive and thus as a materialised way of fore-having the future by taking actions upon it, the strategic group co-creatively came up with ideas for further business development, some of which become adopted and implemented in the organisation. Hence, the business development of the company involved a market development as the economic consultancy services are now offered to new customer segments such as handicraft business, service companies and small production companies. Furthermore, new consultancy services within real estate, insurance and external HR were developed and offered to customers in both the new and existing customer segments. Competences within these new occupational areas were hired to support the business development ideas, as well as employees with a clear business- and sales-oriented mindset, competences and profiles. Hence, the specific ideas of business development materialised into actions of fore-having and became legitimised parts of the institutionalised strategic development of the company.

The new business development ideas produced in the interplay between the Bet and the Before are creative ideas that contradict the grand narrative of a traditional, agricultural, consultancy non-profit association. They are fractal ruptures that break away from the fractal patterns of the traditional grand narrative. The co-creative and co-productive process is facilitated and supported by the open fore-structuring of the Between and the polyphonic fore-conception of the Beneath. Together they facilitate a pluralistic multi-voiced environment for co-creative and co-productive business development: "By organising the strategising process in this way, the company can 
enhance knowledge sharing, dissemination of local expertise and the creation of new ideas for business development. An organisational, cultural pluralistic approach to strategising may thus create an environment in which new initiatives and new strategies may be proposed and enacted (Jarzabkowski and Fenton, 2006) or simply just emerge non-deliberately and unintendedly at the microlevel of activities" (Svane, in press-a, p.12).

The four antenarrative processes of Bet, Before, Between and Beneath are inseparably entangled in the STM dynamics of the organisation it is in the process of becoming. In this entanglement, the antenarrative Becoming process of fore-caring and inquiry is a prerequisite which is explained below.

\section{Antenarrative fore-caring inquiry and new fragmented counternarratives}

The changes of the cross-cultural counternarrative and its stereotyping 'us-them' constructions of cultural identities as well as the break away from the traditional grand narrative of an agricultural non-profit association are storytelling processes that presuppose the fore-caring inquiry of Becoming. Following Heidegger, Being-open in Being-with presupposes the fore-caring and inquiring way of Being-in-the-world according to which Dasein is caring for self, for others, for the relationship, for futures of potentiality and for destiny. Fore-caring is thus made the approach of storytelling inquiry by Boje (2014, p.239).

Fore-caring and inquiry is related to Heidegger's (2008) anticipatory resoluteness and attunement of moods. Anticipation means looking forward to a possible way to be, whereas resoluteness relates to authentically taken ownership of own life by 'taking action' and by being authentic self as opposed to the 'they-self'. An authentic self does not uncritically repeat the usual doings despite its cultural familiarity. This is, however, closely related to our moods and moody wayfaring. According to Heidegger, our moods manifest in how we are faring in the world of Becoming. Attunements relate to the process of being attuned through moods towards emerging events and arriving futures. Due to our fore-caring, moods and attunements, some futures may be more attractive than others (Svane, in press-b, pp.22-23).

Not all organisational members, customers, owners and board of directors felt comfortable with the various choices and actions taken as part of the strategisingorganising process. In fact, the various fragmented subterranean clusters of voices that, to begin with, were hidden by the dominating cross-cultural 'us-them' counternarrative, became visible during the process of becoming. Their voices were critically raised. Almost a whole department as well as many of their customers raised their voices critically towards the strategic direction and toward some of the business developing ideas. In the end, they resolutely decided to leave the company as a group in order to join the competitor.

Other organisational members, customers and owners doubted the strategic direction, questioning the expansion of the main business operation from offering traditional agricultural consultancy to offering more general business consultancy to new nonagricultural customer segments. Furthermore, questions were raised concerning the clashes between an organisational identity and culture of being a non-profit association of farmers and the becoming of a more business and sales oriented organisation. 
However, despite the critical voices, the new business development and strategic direction of the company became more and more institutionalised, making the antenarrative process collapse into a new dominating cultural narrative. The interplay of the emerging hegemonic cultural narrative and the counternarrative of resistance is visualised in the drawing below (Figure 9). The drawing was co-produced by a group of employees put together across the three Houses at a mandatory organisational course. Asked to visualise and draw the future of the company, they came up with this drawing. Later, the drawing was reproduced in the exact same way by a professional artist and distributed as a painting to the three Houses. According to Steven, the dinosaurs symbolise employees who do not agree with the course of change. New stereotypical 'us-them' representations were thus produced, and counternarratives of resistance were silenced by the hegemonic cultural sociality of the merged organisation as well as by the top management.

Figure 9 Change ready team (see online version for colours)

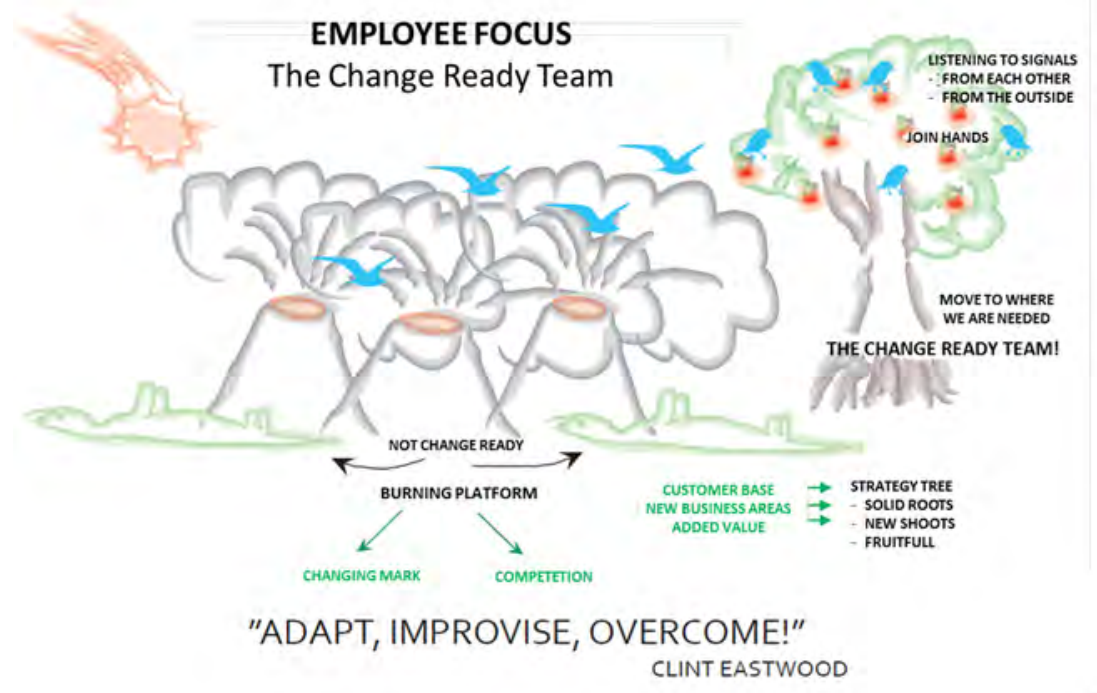

Source: Drawing developed by the employees at the organisation. Employees' copyright. Used by permission.

The collective withdrawal of almost the whole department and the loss of customers came as a shock to the top management and the remaining organisation. The action was unexpected, a non-foreseen fractal rupture breaking away from the new dominating narrative. Once more, the company was left in a vulnerable and difficult economic situation. The incident awakened the organisation, as a new inquiring and sensemaking process was initiated, retrospectively looking backwards and prospectively looking forward to prevent this incident from happening again. Somehow, the lost acts of storytelling was at least for a time restored, as the management of the company acknowledged that they had not listened enough to the signals of resistance and foreseen the possible performative consequences as regard potential arriving futures. 


\section{Discussion}

In this article, we have contributed an antenarrative theory and method that unpacks the relationships between hegemonic cultural narrative and counternarratives of resistance. The five B's antenarrative method of inquiring contributes by uncovering the processes of this relationship as demonstrated in the two cases.

The Beneath, Between, and Becoming aspects of antenarrative praxis are in the microtexture of ritual interactions between organisations and the homeless. There is a microtexture of STM where ritual practices of involvement are what Anton (2001, p.70) calls a ceremonial lamination. Second, these antenarrative practices are in the everyday performances that recognise status differences in Heideggerian 'being-with-others-beingtoward-world' (as cited Anton, p.70). The subtle texture of respect and disrespect as, for example, bystanders who are supposed to be participants in the weekly Great Conversation, have quite limited involvement, as the facilitator and the administrative staff lecture the homeless on civility, obeying the rules, not making MVCH look bad to the city or to donors, etc.

Third, the duration (Heidegger, 1962) of each encounter affects the selfhood qualified expected to endure after the encounter of organisations with the homeless terminates. These are embodied enactments, for example, of how the social workers (nurses, doctors and team leaders) interact with the veterans, which leave a residue of veteran-selfhood that continues, when not confronted by the veteran.

These three antenarrative laminations are entangled, co-implicated and co-comported. Together the antenarrative laminations operate mostly in the prereflexive, in tacit background, as the organisation and homeless go through the everyday habits of interaction. In this everydayness, what Goffman calls the dramaturgical gloss, of ritual, care goes on both at the community agencies and at the VA offices.

The Veterans Theatre, then is an intervention into the anti-narrative laminations, an opportunity to change the texture of everyday encounters between organisation staff and homeless. The audience bears witness to the encounters improvised on the stage, and can glimpse the microevents of antenarrative praxis. The audience is co-experiencing the selfhood of homeless and social workers dwelling in rudeness, in ratification of othering, or in the last act, in a heart-of-care, and in the Forum theatre interplay of having audience members take a role, to improve new ritual practices of staff interacting with homeless (veterans), as hopefully living human beings, instead of abstract characterisations stereotyped in institutional narrative reductions. On the stage, are instantiated a dramaturgy in which the texture of antenarrative praxis of the Selfhood is hermeneutically reimagined and renegotiated, so that encounters of staff and homeless taking on new STM practices.

In the abstract interchangeability of all homeless as this or that stereotype in organisational and societal narratives of everyday encounters perpetuate, form what is called a 'fractal narrative.' In Boje (2015, in press) book, 'Fractal narrative' is defined as 'a narrative that finds its best accomplished form in the Web' in hyperlink networks (Durate, 2014, p.284, bold, italics, mine). In Boje (2015, in press), Boje supplement 'fractal narrative' with a definition of 'fractal story' based on his previous work (2001, 2008, 2011, 2014). “A 'fractal story' is defined here as a web of fluid 'living story 'interrelationships between urban-chaos and fractal-cyber-order that is centrifugal, veering away from order, toward anarchism, discontinuity, and erratic, violent urbanism' (Boje, 2015, in press: 30 in prepublication draft). "A fractal story is a part of a web of 
more and more living stories, always in the middle, some with beginnings, the whole web-work, without end" (ibid.).

The fractal narrative of single hero, with helpers on an adventure that is presented as the whole account with a beginning-middle-end coherence, is what Boje sees in the organisations way of othering the homeless. In the living story fractal, we see a web-work unfolding in the middle, finding their way in the urban anarchy. The BETWEENBENEATH-BECOMING is where the microevents of antenarrative praxis are happening, in the co-experience of staff and homeless in everyday encounters of ritual practices in which the fractal narrative and fractal story are instantiated in the antenarrative texture, and take flight.

The abstracted interchangeability of all homeless persons as this or that stereotype is part of the narrative fractal, a self-similar pattern that iterates through the everyday encounters. Veterans Theatre is an intervention into the micropractices of antenarrative, so that the narrative and the story fractals are disrupted, reimagined, re-dramatised.

Veterans Theatre first plays out the narrative fractal of domination and the living story fractal of alienation, then through Forum Theatre, intervenes in the stereotype, objectification of those encounters of staff with homeless, so that the material conditions can take a new orbit, outside of estrangement.

In Svane and Boje (2015), we developed the Antenarrative Fractal Change Management Model (Figure 10). The model illustrates the antenarrative praxis of zooming in on the microtexture of merging living stories of diverse cultural lifeworlds in the Beneath and on zooming out to capture the tensed and challenging interplay Between living stories as being-with-others-being-toward-world and hegemonic cultural grand narratives. In this tensed relationship, the fractal narrative rules and patterns, for instance, the traditional grand narrative of the agricultural business in place and the stereotypical 'Us-Them' cultural representations, are challenged by the fractal ruptures at the microlevel. The embodied, moody fore-caring inquiry towards the Becoming of the world facilitates the transformations of grand narratives and living stories, as the inquiry operates in the fore-structure and fore-conception of world-making. Without the forecaring inquiry, the dominating cultural grand narrative risks to reduce and silence the novelty of living stories. The authentic Self is reduced to the 'They-Self', alienating the storytellers as the act of storytelling and storylistening is lost. Inquiring, while zooming in and out, is the antecedent antenarrative spatial praxis of managing the transformation process occurring between dominant narrative and counternarrative in the everyday performances..

The spatial antenarrative praxis is inseparably entangled with the temporal dimension of the past, present and future and the meaning-matter entanglement in STM. The STM transformation between the materialised actions of fore-having in the Before and the foretelling of the possible arriving futures in the Bet are part of the process of re-historicising, re-storying and re-telling the past and the future of the organisational lifeworld. The STM texture of the organisation is hermeneutically reimagined and renegotiated similarly to the dramaturgy in the Veterans Theatre. The fore-caring inquiry is also the antecedent of this timespacemattering process of transformations and hence part of the antenarrative managing of fractal change management. 
Figure 10 Antenarrative fractal change management (see online version for colours)

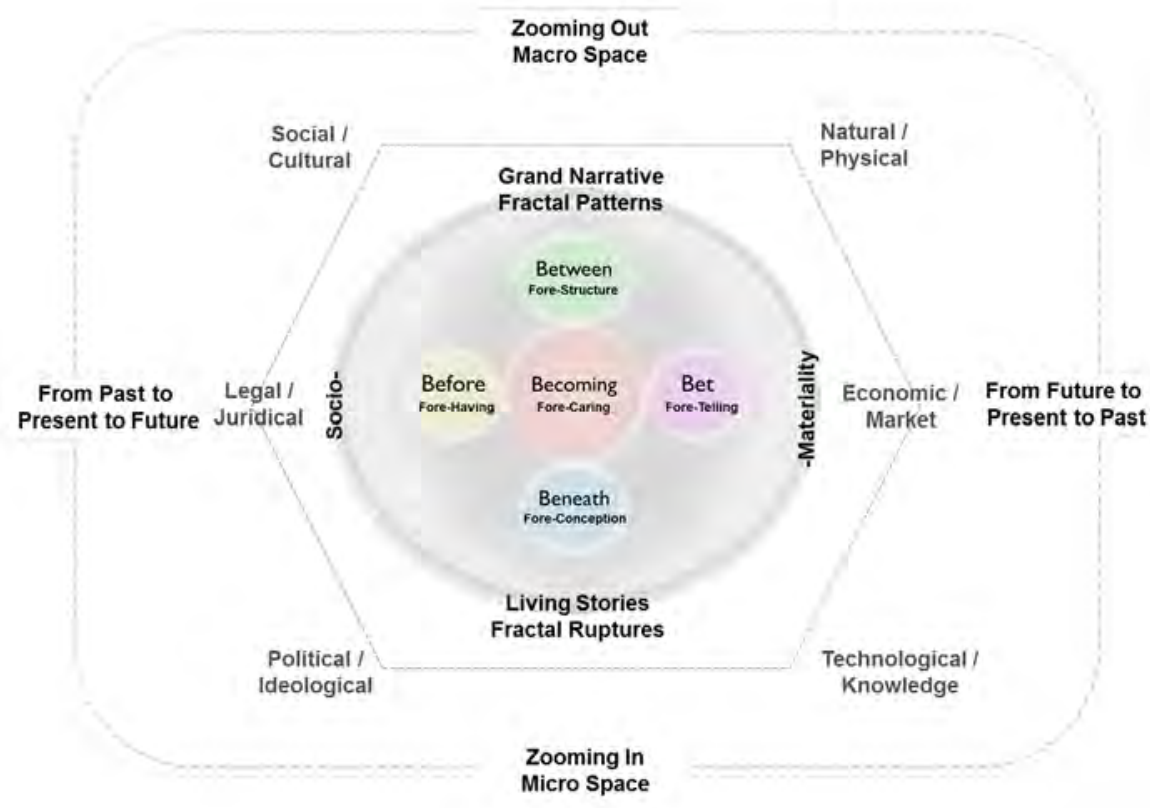

Source: Developed by Svane and Boje (2015).

Consequently, the antenarrative model uncovers the practices of fractal change management as regard managing the relationships between narrative and counternarrative in the practice of power and domination in everyday life performance.

\section{CONCLUSION}

Two case studies were illustrated in this article. Socially dominant narratives were identified, that offered a prevailing definition for each organisation. In comparison, counternarratives were considered for each case. These were self-created narratives, developed by those who had been repressed by the socially dominant narrative. These counternarratives gave voice to the lived experiences of people whose stories had not yet been told.

As these counternarratives emerge, we begin to understand and study their variety. This can lead to new institutional patterns and engagements. In the case of the VA, dialogue between staff and veterans may unfold towards a meaningful process of care and well-being within the constraints of budgets. A new reality may emerge out of the old rituals of assembly-like medicine. In the case of the company merger, the 'us-them' culture was challenged by involvement of employees in developing prospective strategies for the organisation. They were asked to elucidate personal knowledge and everyday life experiences. In these cases, we have shown how storytelling can lead to an interaction and shift between dominant and counter-narratives. 


\section{Notes}

${ }^{1}$ http://www.suitcaseclinic.org/homelessness-defined/

${ }^{2}$ https://investor.lilly.com/releasedetail.cfm?ReleaseID=822044

${ }^{3}$ http://www.fiercepharma.com/story/fda-probes-long-acting-zyprexa-safety-after-2patients-die/2013-06-18

${ }^{4}$ http://www.fiercepharma.com/story/fda-probes-long-acting-zyprexa-safety-after-2patients-die/2013-06-18

${ }^{5}$ http://www.fiercepharma.com/special-reports/top-10-pharma-settlements/eli-lillyzyprexa

${ }^{6}$ p. 4, http://www.va.gov/healthpolicyplanning/vision2020.pdf

${ }^{7}$ p. 4 http://www.va.gov/healthpolicyplanning/vision2020.pdf

${ }^{8}$ Urban Dictionary has several other definitions http://www.urbandictionary.com/ define.php?term=Spice+Head

${ }^{9}$ For more on Spice Addictions see http://spiceaddictionsupport.org/side-effects-of-spiceuse/

\section{References}

Alajaji, S. (2013) 'Performing self: between tradition and modernity in the West Bank', in Kannaaneg, M., Thorsén, S-M., Burshen, H. and McDonald, D.A. (Eds.): Palestinian Music and Song: Expression and Resistance Since 1900. Indiana University Press, Bloomington, IN, pp.97-113.

Anton, C. (2001). Selfhood and Authenticity, State University of New York Press, Albany.

Bakhtin, M.M. (1981) The Dialogic Imagination: Four Essays, University of Texas Press, Austin.

Bakhtin, M.M. (1984) Problems of Dostoevsky's Poetics, University of Minnesota Press, Minneapolis.

Bakhtin, M.M. (1986) Speech Genres and Other Late Essays, Third paperback printing, 1990 edn, University of Texas, Austin, USA.

Banning, K. (1980) 'Conjugating three moments in black Canadian cinema', North of Everything: English-Canadian Cinema Since, pp.84-99.

Boal, A. (1979) Theater of the Oppressed, Theater Communications Group, Inc., New York, NY.

Boal, A. (1995) Rainbow of Desire: The Boal Method of Theatre and Therapy, Routledge, NY/London.

Boje, D.M. (2001) Narrative Methods for Organizational and Communication Research, Sage, London.

Boje, D.M. (2008) Storytelling organizations, Sage, London.

Boje, D. (2011) 'Quantum physics implications of storytelling for socioeconomic research methods: experiences in small business consulting research form New Mexico State University', International Meeting of Research Methods Division of the Academy of Management, Lyon, France.

Boje, D.M. (2012) 'Reflections: what does quantum physics of storytelling mean for change management?', Journal of Change Management, Vol. 12, No. 3, pp.253-271. 
Boje, D.M. (2014) Storytelling Organizational Practices. Managing in the Quantum Age, New York, Routledge.

Boje, D.M. (2015, in press). Change Solutions to the Chaos of Standards and Norms Overwhelming Organizations: Four Wings of Tetranormalizing. Routledge, London/NY.

Boje, D.M. and EnglandKennedy, E., (2013) Embodied Storytelling Healing for Veterans. YouTube video https://www.youtube.com/watch?v=Rni--9m4H7Y

Boje, D., Haley, U.C.V. and Saylors, R. (2015) 'Antenarratives of organizational change: The microstoria of Burger King's storytelling in space, time and strategic context', Journal of Human Relations.

Boje, D.M. and Henderson, T.L. (Eds.) (2014) Being Quantum: Ontological Storytelling in the Age of Antenarrative. Newcastle upon Tyne UK: Cambridge Scholars Publishing.

Boje, D.M., Rosile, G.A., Saylors, J. and Saylors, R. (2015) 'Using storytelling theatrics for leadership training', Advances in Developing Human Resources, Vol. 17, pp.348-362.

Boje, D.M. and Saylors, R. (2013) 'Virtuality and materiality in the ethics of storytelling', in R.T. By and B. Burnes (Eds.): Organizational Change, Leadership and Ethics: Leading Organizations Towards Sustainability, Routledge, NY/London, pp.75-96

Boje, D.M., Svane, M., Henderson, T.L. and Strevel, H.B. (in press) 'Critical corporate social responsibility in tamara-land: The role of tetranormalizing fractals', in R. Ocler (Ed.): Book Chapter for a Springer Collection.

Bonifer, M. (2014) 'Quantum cowboy', in Boje, D.M. and Henderson, T.L. (Eds.): Being Quantum: Ontological Storytelling in the Age of Antenarrative. Newcastle upon Tyne UK: Cambridge Scholars Publishing, pp.11-39.

Bovana, S.V. (2010). Cultural Villages Inherited Tradition and African Culture A case Study of Mgwali Village in the Eastern Cape, Doctoral dissertation, University of Fort Hare. Online at http://contentpro.seals.ac.za/iii/cpro/DigitalItemPdfViewerPage.external?id=17698151213184 91\&itemId=1001317\&lang=eng\&file=\%2Fiii\%2Fcpro\%2Fapp\%3Fid\%3D176981512131849 1\%26itemId\%3D1001317\%26lang\%3Deng\%26nopassword\%3Dtrue\%26service\%3Dblob\%2 6suite\%3Ddef\#locale=eng\&gridView=true

Chia, R.C. and Holt, R. (2009) Strategy Without Design: The Silent Efficacy of Indirect Action, Newcastle upon Tyne, UK: Cambridge University Press.

Chia, R. and Holt, R. (2006) 'Strategy as practical coping: a Heideggerian perspective', Organization Studies, vol. 27, no. 5, pp. 635-655.

Chia, R. and MacKay, B. 2007, Post-processual challenges for the emerging strategy-as-practice perspective: Discovering strategy in the logic of practice, Human Relations, Vol. 60, No. 1, pp.217-242.

Clark, K. and Holquist, M. (1984) Mikhail Bakhtin, Harvard University Press. Cambridge, MA.

Cruikshank, J. (1992) 'Interpreting women's lives: feminist theory and personal narratives', in Personal Narratives Group (Ed.): 1989. p.277, Hardbound, \$39.95; Softbound, \$14.95. Oral History Review, Vol. 20, No. 1, Indiana University Press, Bloomington, pp.132-134.

Davis, C. (1991). 'Understanding the concentration camps: Elie Wiesel's La nuit and Jorge Semprun's Quel beau dimanche!', Australian journal of French studies, Vol. 28, No. 3, pp.291-303.

de Certeau, M. (1998) The Practice of Everyday Life: Living and Cooking. Vol. 2, U of Minnesota Press.

Dunleavy, L.E. (1993) Women's Place, Women's Voice: Counter-Narrative in the Fiction of Melville, Dreiser and Faulkner, Doctoral dissertation, State University of New York, Buffalo.

Durate, G.A. (2014) Fractal Narrative: About the Relationship Between Geometries and Technology and Its Impact on Narrative Spaces, Vol. 12, transcript Verlag, NY: Columbia University Press.

El-Ghadban, Y. and Strohm, K. (2013) 'The ghosts of resistance: dispatches from Palestinian art and music', in M. Kannaaneg, S-M. Thorsén, H. Burshen and D.A. McDonald (Eds.): 
Palestinian Music and Song: Expression and Resistance Since 1900, Indiana University Press, Bloomington, Indiana, pp.175-200

Fink, G., Holden, N. and Lehmann, M. (2007) 'Survival by subversion in former socialist economies: tacit knowledge exchange at the workplace', in K. Hutchings and K. Mohannak (Eds.): Knowledge Management in Developing Economies: A Cross-Cultural and Institutional Approach. Australian Institute of Management/Edward Elgar Publishing, pp.35-51, UK: Edward Elgar.

Flora, Jeane; Boje, David M.; Hacker, Kenneth; and Rosile, Grace Ann (in review) PostDeployment Family Reintegration and Embodied.

Restorying Practices.

German, R.E.N. (2009) Advantaged by the Challenges: Life Histories of High Achieving First Generation College Women of Color, ProQuest LLC, An Arbor, MI. This is a copy of the 2008 dissertation submitted to Michigan State University.

Haley, U.C. and Boje, D.M. (2014) 'Storytelling the internationalization of the multinational enterprise', Journal of International Business Studies (JIBS). http://peaceaware.com/vita/ paper_pdfs/JIBS_Haley_Boje_2014.pdf

Harter, L.N., Scott, J.A., Novak, D.R., Leeman, M. and Morris, J.F. (2006) 'Freedom through flight: performing a counter-narrative of disability', Journal of Applied Communication Research, Vol. 34, No. 1, pp.3-29.

Heidegger, M. (1962) Being and Time. Translated by John Macquarrie and Edward Robinson in 1962 from the 1929 German, with 2008 introduction by Taylor Carmon. Harper Row, New York.

Heidegger, M. (1962 [1927]), Being and Time. Translated by J. Macquarrie and E. Robinson. Oxford: Blackwell

Heidegger, M. (2008) Being and Time, HarperCollins, New York.

Henderson, T. and Boje, D. (2015) Organizational Development and Change Theory. Managing Fractal Organizing Processes. NY/London: Routledge.

Hockenberry, D.P. (2012) 'The ontological phenomenon of the unseen and the unheard that predicts the propensity of futuring ${ }^{\mathrm{TM}}$ within creative and intellectual deviance, intrapreneurship and entrepreneurship', Beyond Sensemaking and Social ConstructivistNarrative, Vol. 64, pp.64-70.

Hosford, A. (2015) 'Las Cruces legalizes tent city’, National City Planning Journal, p.8. Accessed April 25, 2015 at https://hopevillagelascruces.wordpress.com/2015/04/22/las-cruces-andmvch-featured-in-national-city-planning-journal/

Hunt, R. (2007) 'Service-learning: an eye-opening experience that provokes emotion and challenges stereotypes', The Journal of Nursing Education, Vol. 46, No. 6, pp.277-281.

Jarzabkowski, P. and Fenton, E. (2006) 'Strategizing and organizing in pluralistic contexts', Long Range Planning, Vol. 39, No. 6, pp.631-648.

Jorgensen, K., Strand, A. and Boje, D. (2013) 'Towards a postcolonial-storytelling theory of management and organisation', Philosophy of Management, Vol 12, No. 1, pp. 43-66.

Kubayanda, J.B. and Kubayanda, J.B. (1989) 'On discourse of decolonization in Africa and the Caribbean’, Dispositio, Vol. 14, No. 36/38, pp.25-37.

Leo, J. (2008) The Hazards of Telling the Truth, Book Review (April 15, Wall Street Journal online http://www.wsj.com/articles/SB120821739801814533) of Mary Lefkowitz's book, History Lesson.

Lindemann-Nelson, H. (1996) 'Sophie doesn’t', Hypatia, Vol. 11, pp.91-104.

Lindemann-Nelson, H. (1997) 'How to do things with stories', in H. Lindemann-Nelson (Ed.): Stories and Limits: Narrative Approaches to Bioethics, Routledge, New York, pp.vvii-xx.

Lindemann-Nelson, H. (2001) Damaged Identities: Narrative Repair, Cornell University Press, Ithaca, NY. 
Linton, R. (1989) 'Toward a feminist research method', in Alison M.J. and Bordo, S. (Eds.): Gender/Body/Knowledge: Feminist Reconstruction of Being and Knowing, Rutgers University Press, New Brunswick, NJ, pp.273-292.

Lipsitz, G. (1988) 'Mardi Gras Indians: carnival and counter-narrative in black New Orleans', Cultural Critique, University of Minnesota Press, pp.99-121.

Lyotard, J.F. (1979/1984) The Postmodern Condition. Translated by Geoff Bennington and Brian Massumi. University of Minnesota Press, Minneapolis, MN.

Mankekar, P. (1994) 'Reflections on diasporic identities: a prolegomenon to an analysis of political bifocality’, Diaspora: A Journal of Transnational Studies, Vol. 3, No. 3, pp.349-371.

National Coalition for Homeless Veterans. (2015) Background and statistics. Retrieved from http://nchv.org/index.php/news/media/background_and_statistics/

National Institutes of Health. (2008) Addiction science: From molecules to managed care. Retrieved from http://www.drugabuse.gov/publications/addiction-science/relapse

Nourse, J.W. (1997) 'Conservative realists and experimental writers', American Anthropologist, Vol. 99, No. 2, pp.386-387.

Ogundele, W. (1995) Natio, Nation and Postcoloniality: The Example of Ngugi.Ngugi wa Thiong'o: Texts and Contexts. Africa World Press, Inc, Trenton, NJ.

Perl, L. (2014). Veterans and Homelessness. Congressional Research Service Report. No. 7-5700, RL34024. Retrieved from https://www.fas.org/sgp/crs/misc/RL34024.pdf

Pittma, D.J. (1964) 'Homeless men', Society, Vol. 1, No. 2, pp.15-16.

Rosile, G.A., Boje, D.M., Carlon, D.M., Downs, A. and Saylors, R. (2013) 'Storytelling diamond an antenarrative integration of the six facets of storytelling in organization research design', Organizational Research Methods, Vol. 16, No. 4, pp.557-580.

Shane, M. (2009) A different Iranian revolution. New York Times. June 19, 2009, page A27 of the New York edition. Available at http://www.nytimes.com/2009/06/19/opinion/19shane.html? pagewanted $=2 \& \_r=0$

Siddiq, M. (1992) The Making of a Counter-Narrative: Two Examples from Contemporary Arabic and Hebrew Fiction. University of Michigan, Ann Arbor.

Somers, M.R. (1991) Political Culture and the Public Sphere: Rethinking the Making of Citizenship. Working paper \# 459.

Spivak, G.C. (1984) 'Love me, love my ombre, elle’, Diacritics, Vol. 14(4), pp.19-36.

Svane, M. (in press-a) 'Multi-cultural strategizing and organizing in pluralistic context in perspectives on international business - theories and practice', J. Kuada and S.T. Marinova (Eds.): Adonis \& Abbey, London.

Svane, M. (in pressb), Quantum Organizational World-Making-Through Material Embodied Storytelling Practices, Quantum Storytelling Conference 2014.

Svane, M. and Boje, D. (2014) Merger Strategy, Cross-Cultural Involvement and Polyphony, IACCM Conference: Between Cultures and Paradigms 2014.

Svane, M. and Boje, D. (2015) Tamara Land Fractal Change Management-In Between Managerialist Narrative and Polyphonic Living Stories, Sc'Moi, Standing Conference for Management and Organizational Inquiry.

Thomas, J.M. (1993) 'Figures of habit in William James’, New England Quarterly, Vol. 66, No. 1, pp.3-26.

Tsoukas, H. and Chia, R. (2002) 'On organizational becoming: rethinking organizational change', Organization Science, Vol. 13, No. 5, pp.567-582.

Tursi, R. (2005) 'William James's narrative of habit,' Journal of Generalism \& Civics, No. VI (August), pp.55-61.

Tyagi, S. (1995) Counternarrative Strategies: An Analysis of Women's Folk Songs From Northern India. UMI Dissertation Information Service. 
Webster, S.K. (2000) 'Sharing secrets and counternarratives', Psychology of Women Quarterly, Vol. 24, No. 4, pp.384-385.

Westley, C. (2009). Foreword to Planned Chaos Book, pp.vii-x in Von Mises, Ludwig. (1961)

Planned Chaos. An excerpt from Socialism: An Economic \& Sociological Analysis (1951).

Auburn, AL: Ludwig von Mises Institute, published under the Creative Commons Attribution License 3.0

Whittington, R., Molloy, E., Mayer, M. and Smith, A. (2006) 'Practices of strategising/organising: broadening strategy work and skills’, Long Range Planning, Vol. 39, No. 6, pp.615-629.

Whittington, R. (2006) 'Completing the practice turn in strategy research', Organization Studies, Vol. 27, No. 5, pp.613-634. 